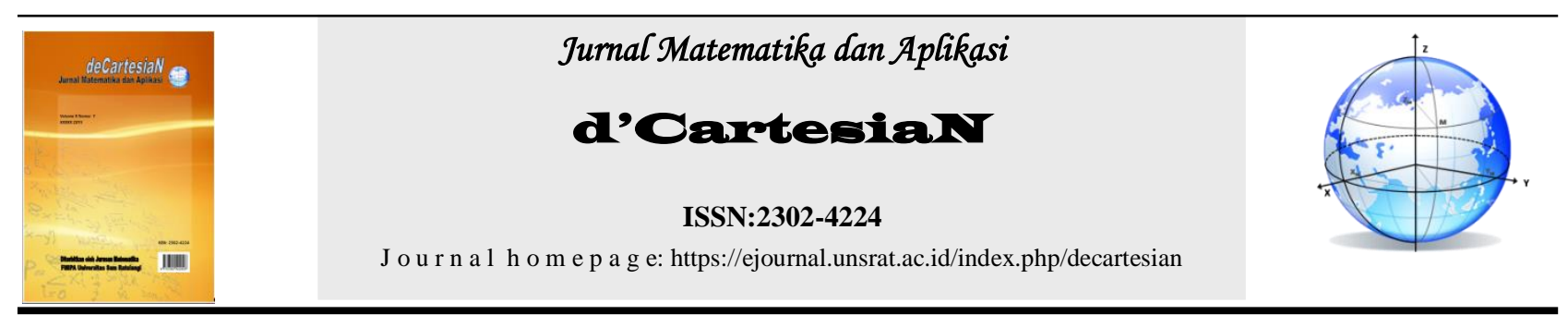

\title{
Penentuan Jalur Terpendek untuk Evakuasi Tsunami di Kelurahan Titiwungen Selatan dengan Menggunakan Algoritma Floyd Warshall dan Algoritma A-Star ( $\left.\mathbf{A}^{*}\right)$
}

\author{
Stephanie E. Chungdinata ${ }^{1}$, Jullia Titaley ${ }^{1}$, Chriestie E.J.C. Montolalu1 ${ }^{{ }^{*}}$ \\ ${ }^{1} J u r u s a n$ Matematika-Fakultas Matematika dan Ilmu Pengetahuan Alam-Universitas Sam Ratulangi Manado, Indonesia
}

${ }^{*}$ Corressponding author : chriestelly@unsrat.ac.id

\section{A B S T R A K}

Kota Manado yang terletak di Sulawesi Utara merupakan salah satu daerah rawan bencana gempa bumi dan tsunami di Indonesia. Sehingga, sangat penting untuk mengetahui jalur evakuasi tsunami di daerah yang berpotensi tsunami di Kota Manado, salah satunya Kecamatan Titiwungen Selatan. Mengacu pada beberapa penelitian sebelumnya, jalur evakuasi akan dimodelkan dengan menggunakan Teori Graf, khususnya konektivitas antar objek pada graf berbobot. Persimpangan jalan akan direpresentasikan sebagai simpul (titik), dan jalur evakuasi tsunami akan direpresentasikan sebagai sisi (garis). Jalur evakuasi terpendek akan dicari dengan membandingkan algoritma Floyd Warshall dan algoritma A-Star $\left(\mathrm{A}^{*}\right)$ karena kedua algoritma ini memiliki karakteristik yang berbeda. Berdasarkan hasil analisis dari algoritma Floyd Warshall dan algoritma A* dapat disimpulkan bahwa dalam penentuan jalur terpendek untuk evakuasi tsunami, hasil dari Algoritma Floyd Warshall lebih optimal karena memiliki bobot yang lebih kecil. Sehingga, jalur terpendek untuk evakuasi tsunami di Kelurahan Titiwungen Selatan diambil dari hasil perhitungan dengan menggunakan Algoritma Floyd Warshall.
\end{abstract}

\section{INFO ARTIKEL}

Diterima : 25 Februari 2019

Diterima setelah revisi : 15 Maret 2019

Tersedia online : 31 Maret 2019

\section{Kata Kunci:}

Jalur Evakuasi Tsunami

Jalur Terpendek

Algoritma Floyd Warshall

Algoritma A-Star $\left(\mathrm{A}^{*}\right)$

\section{PENDAHULUAN}

Indonesia terletak pada pertemuan 3 lempeng tektonik utama dunia yang bergerak relatif saling mendesak satu dengan lainnya. Pergerakan relatif lempeng tektonik tersebut mengakibatkan terjadinya penumpukan tekanan mekanis di daerah-daerah pertemuannya. Saat elastisitas batuan tidak lagi mampu menahan tekanan ini, batuan akan pecah dan melenting menuju kondisi seimbang mendekati kondisi awal sebelum terkena tekanan. Pelentingan ini menimbulkan gempa bumi tektonik. Gempa bumi dengan magnitudo besar (7 SR atau lebih) dengan kedalaman yang dangkal di bawah laut, bisa menimbulkan tsunami karena adanya perubahan ketinggian kolom air dalam waktu singkat [1].

Sulawesi Utara juga merupakan salah satu daerah rawan bencana gempa bumi dan tsunami di Indonesia. Penyebabnya, karena posisi Sulawesi Utara yang terletak dekat dengan sumber gempa bumi dan pembangkit tsunami, baik di darat maupun di laut yang terbentuk akibat proses tektonik. Sumber-sumber gempa di darat berasal dari beberapa sesar aktif yang terletak di daratan Sulawesi Utara. Adapun sumber gempa di laut berasal dari penunjaman sublempeng Sulawesi Utara yang terletak di sebelah utara Pulau Sulawesi, lempeng Punggungan Mayu, dan lempeng Sangihe yang terletak di sebelah timur Sulawesi Utara. Sumber gempa di laut ini juga merupakan sumber pembangkit tsunami [11].
Berada di tiga lempeng yakni Pasifik, Eurasia dan Hindia membuat Provinsi Sulawesi Utara (Sulut) rawan bencana gempa bumi dan tsunami. Tsunami pada tahun 1837 di Manado berupa gelombang air laut besar didahului gempa bumi berkekuatan 8 Skala Richter di Teluk Manado pada kedalaman $11 \mathrm{~km}$, berjarak $150 \mathrm{~km}$ dari arah Pantai Manado. Saat itu, gelombang tsunami setinggi hampir 20 meter memorak morandakan pesisir pantai Manado [8].

Mayoritas daratan Kota Manado berupa barisan pegunungan dan perbukitan. Sedangkan dataran rendahnya berada di sekitar tepi pantai. Sebagian wilayah Kota Manado juga dibatasi oleh pantai dengan garis pantai membentang sepanjang $\pm 18 \mathrm{Km}$. Sedangkan di sebelah Barat Laut, wilayah Manado juga meliputi perairan dimana di wilayah perairan tersebut terdapat 3 pulau besar, yaitu Manado Tua, Bunaken, dan Siladen [18].

Karena Kota Manado merupakan salah satu daerah yang rawan mengalami bencana gempa bumi dan tsunami, maka sangat penting untuk mengetahui jalur evakuasi tsunami di daerah yang berpotensi terjadi tsunami di kota Manado, salah satunya Kecamatan Titiwungen Selatan.

Mengacu pada beberapa penelitian sebelumnya [2] dan [10], jalur evakuasi tsunami dapat dimodelkan dengan menggunakan Teori Graf. Penggunaan Teori graf terlebih khusus dalam menentukan konektivitas antar objek pada graf 
berbobot. Dalam penelitian ini tidak digunakan graf berarah karena penelitian ini dapat digunakan oleh pemerintah dalam pembuatan rambu-rambu evakuasi tsunami di setiap persimpangan jalan, sehingga saat terjadi tsunami warga hanya perlu mengikuti rambu-rambu yang ada.

Objek bisa direpresentasikan oleh titik atau simpul, sedangkan konektivitasnya direpresentasikan oleh garis atau sisi. Selanjutnya, kita dapat menyelesaikan permasalahan yang telah dimodelkan dan mendapatkan hasil akhir yang optimal. Dalam penelitian ini persimpangan jalan akan direpresentasikan sebagai titik atau simpul, sedangkan jalur evakuasi tsunami akan direpresentasikan sebagai garis atau sisi.

Algoritma $\mathrm{A}^{*}$ dikatakan mirip dengan algoritma Dijkstra, namun pada algoritma $A^{*}$ menggunakan informasi tambahan (nilai heuristik) dalam pencarian solusi, dimana pada algoritma Dijkstra nilai heuristiknya selalu o (nol) sehingga tidak ada fungsi yang mempermudah pencarian solusinya [12].

Sedangkan, algoritma Floyd Warshall adalah algoritma yang membandingkan semua jalur yang mungkin melalui grafik antara masing-masing simpul [7].

Karena kedua algoritma di atas memiliki karakteristik yang berbeda, maka dalam penelitian ini, penyelesaian jalur terpendek evakuasi tsunami akan dicari menggunakan algoritma $\mathrm{A}^{*}$ (A-star atau A-bintang) dan algoritma Floyd Warshall. Kedua algoritma ini akan dibandingkan dan akan dilihat manakah algoritma yang lebih cocok untuk menentukan jalur terpendek untuk evakuasi tsunami.

\section{TINJAUAN PUSTAKA}

\subsection{Bencana}

UU No. 24 tahun 2007 tentang Penanggulangan Bencana menyatakan bahwa, "bencana adalah peristiwa atau rangkaian peristiwa yang mengancam dan mengganggu kehidupan dan penghidupan masyarakat yang disebabkan, baik oleh faktor alam dan/atau faktor nonalam maupun faktor manusia sehingga mengakibatkan timbulnya korban jiwa manusia, kerusakan lingkungan, kerugian harta benda, dan dampak psikologis. Sedangkan bencana alam adalah bencana yang diakibatkan oleh peristiwa atau serangkaian peristiwa yang disebabkan oleh alam antara lain berupa gempa bumi, tsunami, gunung meletus, banjir, kekeringan, angin topan, dan tanah longsor".

\subsection{Sistem Pendukung Keputusan}

\subsubsection{Pengertian Tsunami}

Tsunami berasal dari bahasa Jepang yang berarti gelombang ombak lautan ("tsu" berarti lautan, "nami" berarti gelombang ombak). Tsunami adalah serangkaian gelombang ombak laut raksasa yang timbul karena adanya pergeseran di dasar laut akibat gempa bumi [16].

Tsunami adalah gelombang air laut yang merambat ke segala arah dan terjadi karena adanya gangguan impulsif pada dasar laut. Gangguan impulsif terjadi karena perubahan bentuk struktur geologis dasar laut secara vertikal utamanya dan dalam waktu singkat. Perubahan tersebut disebabkan oleh tiga sumber utama, yaitu gempa bumi tektonik, letusan gunung api, atau longsoran yang terjadi di dasar laut. Berdasarkan ketiga sumber tersebut, penyebab utama tsunami di Indonesia adalah gempa bumi tektonik [1].

Tidak semua gempa bumi tektonik mengakibatkan tsunami, tetapi sebagian besar tsunami disebabkan oleh gempa bumi. Gempa bumi yang dapat memicu tsunami memiliki kriteria sebagai berikut [1]:

1. Gempa bumi tektonik terjadi di bawah laut.

2. Kedalaman (hiposenter) gempa bumi kurang dari $100 \mathrm{~km}$.

3. Kekuatan 7 Skala Richter (SR) atau lebih.

4. Pergerakan lempeng tektonik terjadi secara vertikal, mengakibatkan dasar laut naik/turun, dan mengangkat/menurunkan kolom air di atasnya.

\subsubsection{Pengertian Tsunami}

Indonesia merupakan negara yang rawan terhadap tsunami, terutama daerah-daerah pantai yang berhadapan langsung dengan pertemuan Lempeng Eurasia, Indo-Australia dan Pasifik, antara lain bagian barat Pulau Sumatera, selatan Pulau Jawa, Nusa Tenggara, bagian utara Papua, Sulawesi dan Maluku, serta bagian timur Pulau Kalimantan [1].

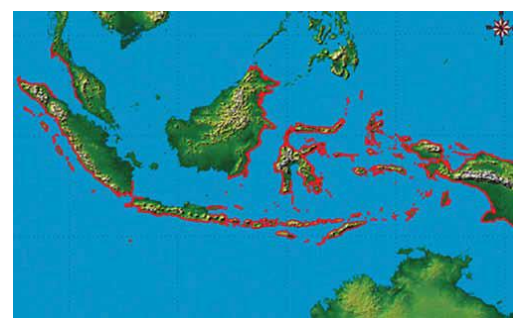

Gambar 1. Peta daerah rawan tsunami di Indonesia

Sutopo menerangkan, untuk potensi bencana tsunami, Indonesia menempati peringkat pertama dari 265 negara di dunia yang disurvei badan PBB itu. Resiko ancaman tsunami di Indonesia bahkan lebih tinggi dibandingkan Jepang. Dalam itungitungan UNISDR, kata Sutopo, ada 5.402.239 orang yang berpotensi terkena dampaknya [17].

\subsection{Teori Graf}

\subsubsection{Sejarah Teori Graf}

Sungai Pregolya melawati sebuah Kota yang dikenal sebagai Königsberg. Pada tahun 1700-an, tujuh jembatan yang terletak menyebrangi sungai ini seperti yang terlihat pada Gambar 2. Penduduk kota melewati jembatan-jembatan ini, tetapi, sesulit apapun mereka mencoba, tidak ada penduduk yang dapat melewati masing-masing jembatan ini tepat satu kali. Seorang Matematikawan Swiss bernama Leonhard Euler mempelajari fenomena ini, dan pada tahun 1736 ia menulis sebuah artikel yang berjudul "Solutio problematis ad geometriam situs pertinentis" tentang fenomena ini. Karyanya atas 
"Masalah Jembatan Königsberg" dianggap banyak orang sebagai awal dari Teori Graf [3].

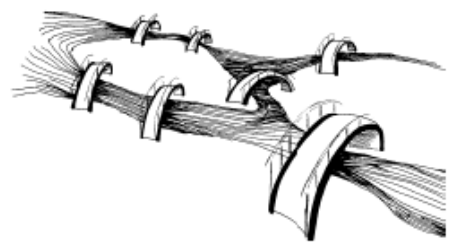

Gambar 2. Jembatan-jembatan di Königsberg

Graf digunakan untuk merepresentasikan objek-objek diskrit dan hubungan antara objekobjek tersebut. Representasi visual dari graf adalah dengan menyatakan objek dinyatakan dengan noktah, bulatan, atau titik, sedangan hubungan antara objek dinyatakan dengan garis [4].

\section{Definisi}

Sebuah graf $G=(V, E)$ terdiri atas $V$, sebuah himpunan titik-titik (vertices) yang tidak kosong dan $E$, sebuah himpunan garis-garis (edges). Setiap garis memiliki antara satu atau dua titik-titik yang terhubung dengannya, yang disebut titik-titik ujungnya (endpoints) [9].

\subsubsection{Jenis-Jenis Graf}

Graf dapat dikelompokkan menjadi beberapa kategori (jenis) bergantung pada sudut pandang pengelompokannya. Pengelompokan graf dapat dipandang berdasarkan ada tidaknya sisi ganda atau sisi kalang atau berdasarkan orientasi arah pada sisi [4].

Berdasarkan ada tidaknya gelang atau sisi ganda pada suatu graf, maka secara umum graf dapat digolongkan menjadi dua jenis [4]:

1. Graf sederhana (simple graph)

Graf yang tidak mengandung gelang maupun sisi-ganda dinamakan graf sederhana. $G_{1}$ pada Gambar 3(a) adalah contoh graf sederhana. Pada graf sederhana, sisi adalah pasangan takterurut (unordered pairs). Jadi, menuliskan sisi $(u, v)$ sama saja dengan $(v, u)$. Kita dapat juga mendefinisikan graf sederhana $G=(V, E)$ terdiri dari himpunan tidak kosong simpulsimpul dan $\mathrm{E}$ adalah himpunan pasangan takterurut yang berbeda yang disebut sisi.

2. Graf tak-sederhana (unsimple-graph)

Graf yang mengandung sisi ganda atau gelang dinamakan graf tak-sederhana. Ada dua macam graf tak-sederhana, yaitu graf ganda (multigraph) dan graf semu (pseudograph).

Graf ganda adalah graf yang mengandung sisi ganda (multiple edges atau paralel edges). Sisi ganda yang menghubungkan sepasang simpul bisa lebih dari dua buah. $G_{2}$ pada Gambar 3(b) adalah contoh graf ganda karena memiliki sisi $e_{3}$ dan $e_{4}$ yang merupakan sisi-ganda. Sisi ganda dapat diasosiasikan sebagai pasangan tak-terurut yang sama. Kita dapat juga mendefinisikan graf ganda $G=(V, E)$ terdiri dari himpunan tidak kosong simpul-simpul dan $E$ adalah himpunan-ganda (multiset) yang mengandung sisi ganda.
Graf semu adalah graf yang mengandung gelang atau kalang (loop). $G_{3}$ pada Gambar 3(c) adalah contoh graf semu karena memiliki sisi $e_{8}$ yang merupakan gelang. Graf semu lebih umum daripada graf ganda, karena sisi pada graf semu terhubung ke dirinya sendiri.

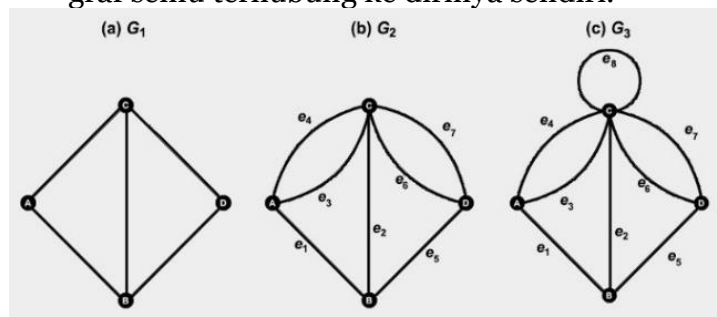

Gambar 3. Tiga buah graf (a) graf sederhana, (b) graf ganda, dan (c) graf semu

\subsubsection{Terminologi (Istilah) Dasar}

1. Bertetangga (Adjacent)

Dua buah simpul pada graf tak-berarah $G$ dikatakan bertetangga bila keduanya terhubung langsung dengan sebuah sisi. Dengan kata lain, $u$ bertetangga dengan $v$ jika $(u, v)$ adalah sebuah sisi pada graf $G$. Pada Gambar 4(a), simpul A bertetangga dengan simpul B dan C, tetapi simpul A tidak bertetangga dengan simpul D [4].

2. Bersisian (Incident)

Untuk sembarang sisi $e=(u, v)$, sisi $e$ dikatakan bersisian dengan simpul $u$ dan simpul v. Pada Gambar 4(b), sisi (B, C) bersisian dengan simpul $\mathrm{B}$ dan simpul $\mathrm{C}$, sisi (B, D) bersisian dengan simpul B dan simpul D, tetapi sisi (A, B) tidak bersisian dengan simpul C [4].

3. Simpul Terpencil (Isolated Vertex)

Simpul terpencil ialah simpul yang tidak mempunyai sisi yang bersisian dengannya. Atau dapat juga dinyatakan bahwa simpul terpencil adalah simpul yang tidak satupun bertetangga dengan simpul-simpul lainnya. Pada Gambar 4(c), simpul E adalah simpul terpencil [4].
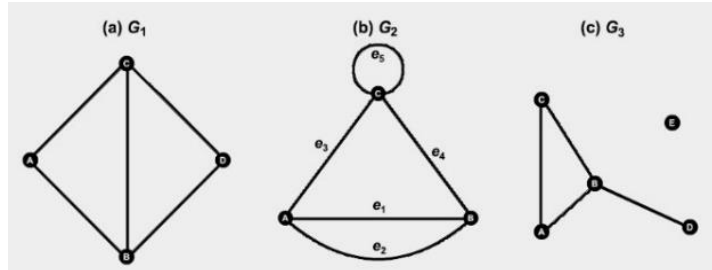

Gambar 4. Tiga Buah Graf (a) $G_{1}$, (b) $G_{2}$, dan (c) $G_{3}$

4. Graf Kosong (Null Graph atau Empty Graph) Graf yang himpunan sisinya merupakan himpunan kosong disebut sebagai graf kosong dan ditulis sebagai $N_{n}$ yang dalam hal ini $n$ adalah jumlah simpul [4].

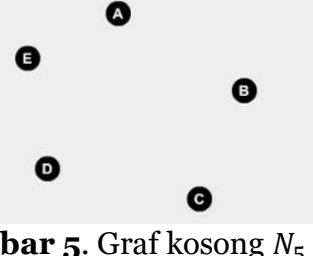

Gambar 5. Graf kosong $N_{5}$ 
5. Derajat (Degree)

Derajat suatu simpul pada graf tak-berarah adalah jumlah sisi yang bersisian dengan simpul tersebut. Notasi $d(v)$ menyatakan derajat $\operatorname{simpul} v[4]$.

6. Konektivitas (Connectivity)

Suatu walk di graf $G$ adalah urutan bolak-balik $W: v_{0}, e_{1}, v_{1}, e_{2}, v_{2}, \ldots, v_{n-1}, e_{n}, v_{n}$ dari titiktitik dan garis-garis seperti $e_{i}=v_{i-1} v_{i}$ untuk $i=1,2, \ldots, n$. Walk yang berawal dari $v_{0}$ dan berakhir di $v_{n}$ disebut suatu walk $v_{0}-v_{n}$ dan jumlah garis-garis (tidak harus berbeda) dalam suatu walk disebut panjang dari walk. Walk $v_{0}-v_{n}$ dikatakan tertutup jika $v_{0}=v_{n}$ dan dikatakan terbuka jika $v_{0} \neq v_{n}$. Walks tertutup disebut juga sebagai circuits. Walk $W$ dapat disimbolkan hanya dengan menulis $W$ : $v_{0}, v_{1}, v_{2}, \ldots, v_{n}$. Suatu trail adalah sebuah walk dimana tidak ada garis yang berulang. Suatu path adalah sebuah walk terbuka dimana tidak ada titik yang berulang. Suatu cycle adalah walk tertutup dimana tidak ada titik kecuali titik awal yang berulang [14].

7. Terhubung (Connected)

Graf tak-berarah $G$ disebut graf terhubung (connected graph) jika untuk setiap pasang simpul $u$ dan $v$ di dalam himpunan $V$ terdapat lintasan dari $u$ ke $v$. Jika tidak, maka $G$ disebut graf tak-terhubung (disconnected graph). Graf yang hanya terdiri atas satu simpul saja (tidak ada sisi) tetap dikatakan terhubung [4].

\subsection{Algoritma}

\subsubsection{Algoritma $A^{*}$}

Algoritma A* pertama kali diperkenalkan pada 1968 oleh Peter Hart, Nils Nilsson, dan Bertram Raphael, yang dinamakan algoritma A. Penggunaan fungsi heuristik yang tepat pada algoritma A sehingga dapat memberikan hasil yang optimal mengakibatkan algoritma ini berkembang menjadi $\mathrm{A}^{*}$ [5].

$\mathrm{A}^{*}$ adalah gabungan algoritma Dijkstra dan Best First untuk mengkompensasikan kelemahan-kelemahan dari masing-masing algoritma [2].

Algoritma $A^{*}$ adalah algoritma pencarian terbaik dalam mencari jalur terpendek dengan perhitungan terkecil pada jalur dengan titik awal menuju titik akhir. Perhitungan pada Algoritma $\mathrm{A}^{*}$ dapat ditentukan sebagai berikut:

a. $G(n)$ adalah nilai pada pergerakan titik awal menuju titik berikutnya.

b. $H(n)$ adalah perkiraan nilai pergerakan titik awal menuju tujuan akhir titik.

c. $\quad F(n)$ adalah jumlah nilai dari fungsi $G(n)$ dan $H(n)$ dengan nilai terkecil $F(n)$ adalah jalur terpendek menuju tujuan akhir.

Secara singkat algoritma $\mathrm{A}^{*}$ dapat ditulis sebagai [5]:

$$
F(n)=G(n)+H(n)
$$

Algoritma $\mathrm{A}^{*}$ dinilai optimal jika $H(n)$ adalah admissible heuristic, yaitu jarak dengan menarik garis lurus karena jarak terdekat dari dua titik adalah dengan menarik garis lurus [15].
Algoritma Floyd Warshall adalah algoritma penghitungan jalur terpendek yang dapat mencari semua jarak dari tiap simpul (all pairs shortest path) yang artinya dapat digunakan untuk menghitung bobot terkecil dari semua jalur yang menghubungkan sebuah pasangan titik, dan melakukannya sekaligus untuk semua pasangan titik [6].

Algoritma Floyd Warshall menggunakan matriks dua dimensi sebagai representasi dari sebuah jaringan. Jika suatu jaringan terdiri dari $n$ buah sisi berarah (arc) maka matriks yang akan dibentuk oleh algoritma floyd untuk proses penghitungan adalah sebesar $n \times n$. Matriks ini merepresentasikan bobot $w$ dari keseluruhan arc yang ada pada graf $(V, E)$ dengan $w(i, j)$ dimana $i$ adalah titik (node) awal dan $j$ adalah titik (node) tujuan [6].

Bobot dari titik $i$ ke titik $j$ atau $w(i, j)$ mempunyai tiga kemungkinan nilai, yaitu [6]:

a. $\quad w(i, j)=0$ jika $i=j$ (dari titik $i$ ke $i$ itu sendiri)

b. $\quad w(i, j)=$ bobot $\operatorname{arc}$ jika $i \neq j$ dan titik $i$ terhubung dengan titik $j$

c. $\quad w(i, j)=\infty$ jika $i \neq j$ dan titik $i$ tidak terhubung dengan titik $j$

\section{METODE PENELITIAN}

\subsection{Waktu dan Tempat Penelitian}

Penelitian ini dilaksanakan selama bulan Oktober 2018 sampai Januari 2019, mulai dari penyusunan proposal, pengambilan data serta pengolahan data. Pengambilan data dari Badan Nasional Penanggulangan Bencana dan pengolahan data dilakukan di Laboratorium Komputer Lanjut, Fakultas Matematika dan Ilmu Pengetahuan Alam, Universitas Sam Ratulangi Manado.

\subsection{Analisis Data}

Sumber pengumpulan data yang digunakan dalam penelitian ini adalah data sekunder. Adapun data sekunder yang diperoleh berupa informasi yang diperoleh dari Badan Nasional Penanggulangan Bencana (BNPB). Metode yang digunakan dalam karya tulis ini adalah analisa studi literatur. Sumber yang digunakan berasal dari buku, jurnal ilmiah, dan artikel di internet.

Langkah-langkah:

1. Pengambilan data

2. Membuat graf berdasarkan peta Kota Manado khususnya Kecamatan Titiwungen Selatan, dimana persimpangan jalan akan direpresentasikan sebagai titik atau simpul dan jalur evakuasi tsunami akan direpresentasikan sebagai garis atau sisi.

3. Menentukan solusi optimal menggunakan Algoritma Floyd Warshall dan Algoritma AStar $\left(\mathrm{A}^{*}\right)$.

4. Membandingkan hasil dari masing-masing algoritma dan menentukan algoritma yang lebih cocok untuk menentukan jalur evakuasi terpendek.

5. Mendapatkan hasil optimal jalur evakuasi bencana tsunami terpendek. 
Tabel 1. Daerah yang Beresiko Tsunami di Kota Manado

\begin{tabular}{|l|l|l|l|l|}
\hline $\begin{array}{c}\text { Kode } \\
\text { Kecamatan }\end{array}$ & $\begin{array}{c}\text { Nama } \\
\text { Kecamatan }\end{array}$ & $\begin{array}{c}\text { Luas } \\
\text { Risiko } \\
\text { (Ha) }\end{array}$ & $\begin{array}{c}\text { Jiwa } \\
\text { Terpapar } \\
\text { (Orang) }\end{array}$ & $\begin{array}{c}\text { Fisik } \\
\text { (Rp. milyar) }\end{array}$ \\
\hline 7171010 & Malalayang & 70 & 3.743 & 9.796 \\
\hline 7171020 & Sario & 52 & 6.135 & 16.080 \\
\hline 7171030 & Wenang & 57 & 1.996 & 282.096 \\
\hline 7171052 & Tuminting & 37 & 7.076 & 15.039 \\
\hline 7171053 & Bunaken & 44 & 909 & 1.174 \\
\hline 7171054 & $\begin{array}{l}\text { Bunaken } \\
\text { Kepulauan }\end{array}$ & 96 & 1.139 & 4.306 \\
\hline
\end{tabular}

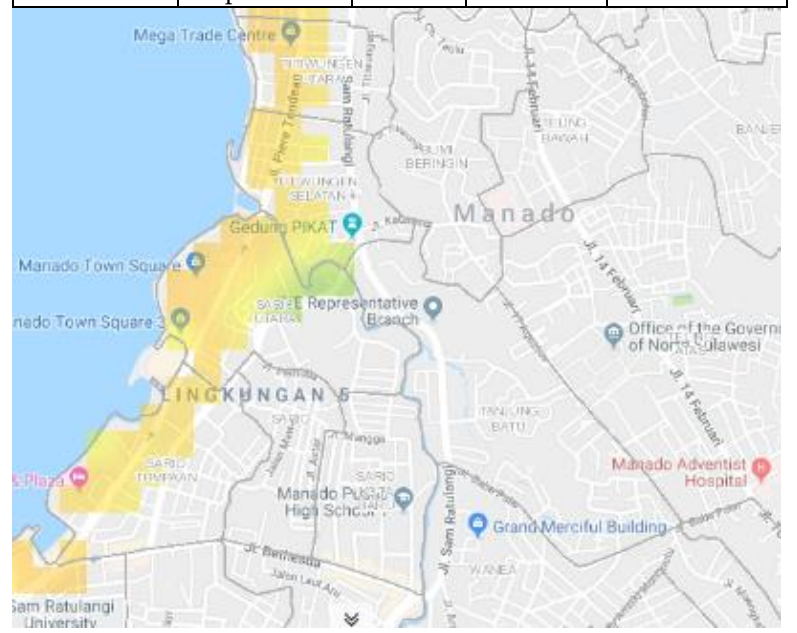

Gambar 6. Peta Kelurahan Titiwungen Selatan Sumber: http://inarisk.bnpb.go.id

\section{HASIL DAN PEMBAHASAN}

\subsection{Hasil}

\subsubsection{Kelurahan Titiwungen Selatan}

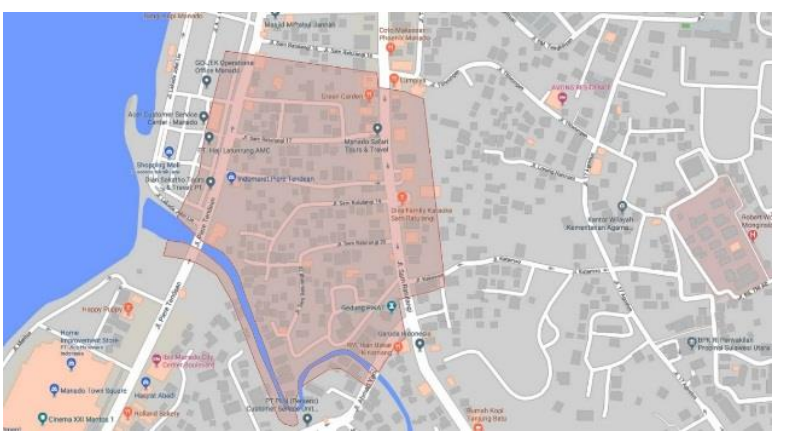

Gambar 7. Peta Kelurahan Titiwungen Selatan

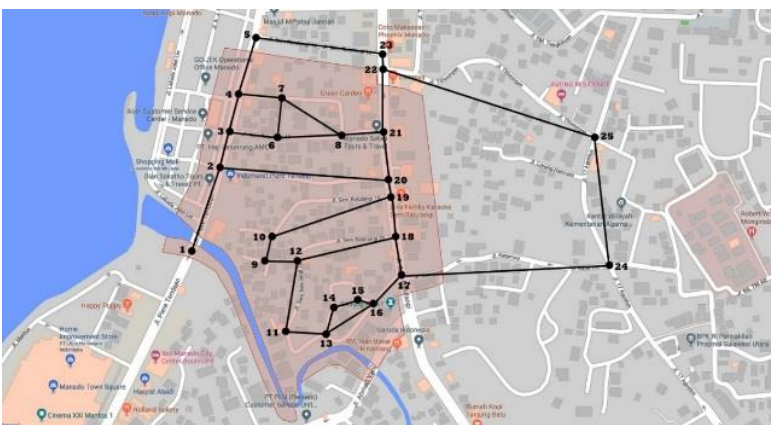

Gambar 8. Graf Kelurahan Titiwungen Selatan

\subsubsection{Bobot pada Graf}

Keterangan tabel untuk bobot dari titik $i$ ke titik $j$ :

a. $\square$ : jika $i=j$ (dari titik $i$ ke $i$ itu sendiri)

b. $\square$ : jika $i \neq j$ dan titik $i$ terhubung dengan titik $j$

c. $\square$ : jika $i \neq j$ dan titik $i$ tidak terhubung dengan titik $j$

Tabel 2. Bobot Pertama (Jarak)

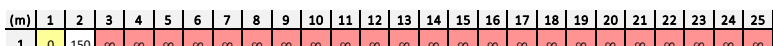

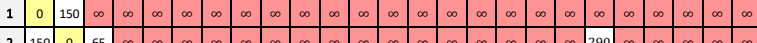

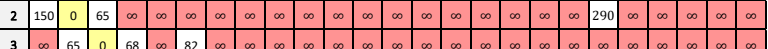
\begin{tabular}{l|lllllllllllllllllllllllllllllll}
\hline 4 & $\infty$ & $\infty$ & 68 & 0 & 100 & $\infty$ & 77 & $\infty$ & $\infty$ & $\infty$ & $\infty$ & $\infty$ & $\infty$ & $\infty$ & $\infty$ & $\infty$ & $\infty$ & $\infty$ & $\infty$ & $\infty$ & $\infty$ & $\infty$ & $\infty$ & $\infty$ & $\infty$ \\
\hline 5 & $\infty$ & $\infty$ & $\infty$ & 10 & 0 & & &
\end{tabular}

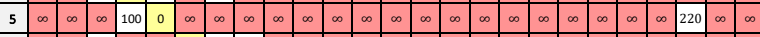

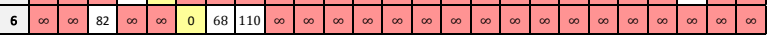

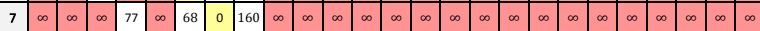

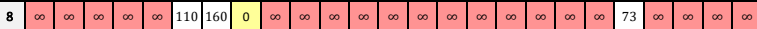
\begin{tabular}{lllllllllllllllllllllllllll|}
\hline 9 & $\infty$ & $\infty$ & $\infty$ & $\infty$ & $\infty$ & $\infty$ & $\infty$ & $\infty$ & 0 & 46 & $\infty$ & 58 & $\infty$ & $\infty$ & $\infty$ & $\infty$ & $\infty$ & $\infty$ & $\infty$ & $\infty$ & $\infty$ & $\infty$ & $\infty$ & $\infty$ & $\infty$ \\
\hline 10 & $\infty$ & $\infty$ & & $\infty$ & & & $\infty$ & $\infty$ & 4 & 0 & $\infty$ & & $\infty$ & $\infty$ & $\infty$ & $\infty$ & $\infty$ & $\infty$ & 23 & & $\infty$ & $\infty$ & $\infty$ & $\infty$ & $\infty$ \\
\hline
\end{tabular} \begin{tabular}{lllllllllllllllllllllllllllll}
10 & $\infty$ & $\infty$ & $\infty$ & $\infty$ & $\infty$ & $\infty$ & $\infty$ & $\infty$ & 46 & 0 & $\infty$ & $\infty$ & $\infty$ & $\infty$ & $\infty$ & $\infty$ & $\infty$ & $\infty$ & 230 & $\infty$ & $\infty$ & $\infty$ & $\infty$ & $\infty$ & $\infty$ \\
\hline
\end{tabular}

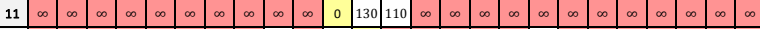

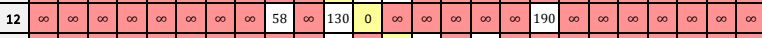
\begin{tabular}{l|llllllllllllllllllllllllllllllll}
\hline 13 & $\infty$ & $\infty$ & $\infty$ & $\infty$ & $\infty$ & $\infty$ & $\infty$ & $\infty$ & $\infty$ & $\infty$ & 110 & $\infty$ & 0 & 43 & $\infty$ & 120 & $\infty$ & $\infty$ & $\infty$ & $\infty$ & $\infty$ & $\infty$ & $\infty$ & $\infty$ & $\infty$ \\
\hline
\end{tabular} \begin{tabular}{lllllllllllllllllllllllllll}
14 & $\infty$ & $\infty$ & $\infty$ & $\infty$ & $\infty$ & $\infty$ & $\infty$ & $\infty$ & $\infty$ & $\infty$ & $\infty$ & $\infty$ & 43 & 0 & 42 & $\infty$ & $\infty$ & $\infty$ & $\infty$ & $\infty$ & $\infty$ & $\infty$ & $\infty$ & $\infty$ & $\infty$ \\
\hline
\end{tabular} \begin{tabular}{lllllllllllllllllllllllllll}
\hline 15 & $\infty$ & $\infty$ & $\infty$ & $\infty$ & $\infty$ & $\infty$ & $\infty$ & $\infty$ & $\infty$ & $\infty$ & $\infty$ & $\infty$ & $\infty$ & 42 & 0 & 35 & $\infty$ & $\infty$ & $\infty$ & $\infty$ & $\infty$ & $\infty$ & $\infty$ & $\infty$ & $\infty$ \\
\hline
\end{tabular}

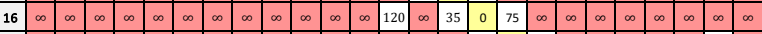
\begin{tabular}{l|llllllllllllllllllllllllllll}
\hline 17 & $\infty$ & $\infty$ & $\infty$ & $\infty$ & $\infty$ & $\infty$ & $\infty$ & $\infty$ & $\infty$ & $\infty$ & $\infty$ & $\infty$ & $\infty$ & $\infty$ & $\infty$ & 75 & 0 & 60 & $\infty$ & $\infty$ & $\infty$ & $\infty$ & $\infty$ & 350 & $\infty$ \\
\hline
\end{tabular} \begin{tabular}{lllllllllllllllllllllllllllll}
\hline 18 & $\infty$ & $\infty$ & $\infty$ & $\infty$ & $\infty$ & $\infty$ & $\infty$ & $\infty$ & $\infty$ & $\infty$ & $\infty$ & 190 & $\infty$ & $\infty$ & $\infty$ & $\infty$ & 60 & 0 & 70 & $\infty$ & $\infty$ & $\infty$ & $\infty$ & $\infty$ & $\infty$ \\
\hline
\end{tabular}

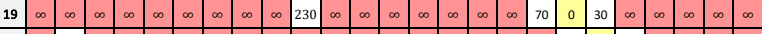
\begin{tabular}{lllllllllllllllllllllllllll}
\hline 20 & $\infty$ & 290 & $\infty$ & $\infty$ & $\infty$ & $\infty$ & $\infty$ & $\infty$ & $\infty$ & $\infty$ & $\infty$ & $\infty$ & $\infty$ & $\infty$ & $\infty$ & $\infty$ & $\infty$ & $\infty$ & 30 & 0 & 86 & $\infty$ & $\infty$ & $\infty$ & $\infty$ \\
\hline
\end{tabular}

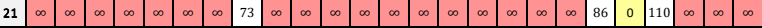

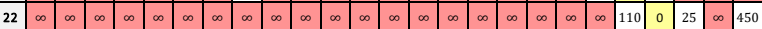

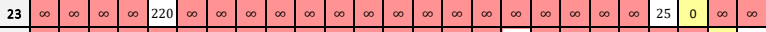

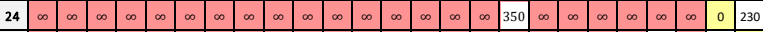
\begin{tabular}{l|lllllllllllllllllllllllllllll}
25 & $\infty$ & $\infty$ & $\infty$ & $\infty$ & $\infty$ & $\infty$ & $\infty$ & $\infty$ & $\infty$ & $\infty$ & $\infty$ & $\infty$ & $\infty$ & $\infty$ & $\infty$ & $\infty$ & $\infty$ & $\infty$ & $\infty$ & $\infty$ & $\infty$ & 450 & $\infty$ & 230 & 0 \\
\hline
\end{tabular}

Tabel 3. Bobot kedua (Akses Jalan)

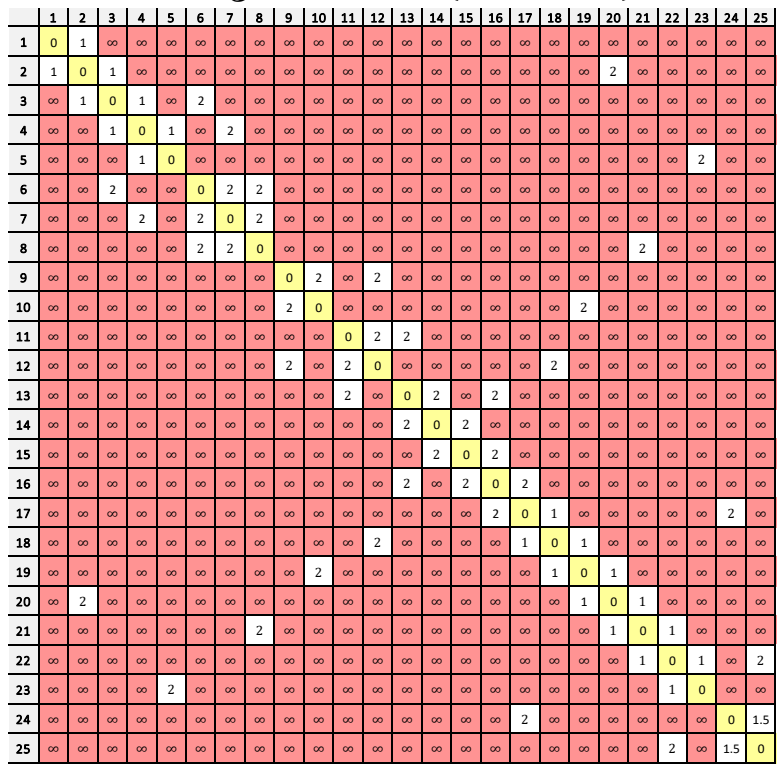

Pada penelitian ini, dilakukan perencanaan jalur evakuasi tsunami ditekankan bagi pejalan kaki karena menyesuaikan himbauan dari [19] tentang tips siaga bencana tsunami. Pada bobot kedua, yaitu akses jalan, terdapat 3 kategori bobot. Kategori pertama bernilai 1 yang berarti jalan dengan akses paling mudah (jalan lebar dan te rdapat beberapa rumah penduduk), kategori kedua bernilai 1.5 yang berarti jalan dengan akses sedang (jalan tidak terlalu lebar dan terdapat beberapa 
rumah penduduk), dan kategori ketiga bernilai 2 yang berarti jalan dengan akses paling sulit (jalan kecil dan banyak rumah penduduk). Karena, jika ada banyak orang yang berjalan secara bersamaan pada jalan yang jaraknya sama tetapi tingkat kesulitan akses jalannya berbeda, akan lebih mudah berjalan di jalan yang aksesnya mudah dibandingkan yang aksesnya sulit.

Akses jalan ini ditentukan berdasarkan lebar jalan dan adanya rumah penduduk. Pemilihan bobot tidak bisa terlalu jauh karena akan mempengaruhi perbandingan jarak yang sebenarnya.

Tabel 4. Bobot Graf

\begin{tabular}{|c|c|c|c|c|c|c|c|c|c|c|c|c|c|c|c|c|c|c|c|c|c|c|c|c|c|}
\hline & & & & & & & & & & & & & & & & & & & & & & & & & \\
\hline & & 150 & $\infty$ & $\infty$ & $\infty$ & $\infty$ & $\infty$ & $\infty$ & $D_{\infty}$ & $\infty$ & & $\infty$ & & & & $\infty$ & $\infty$ & $\infty$ & $\infty$ & - & $\infty$ & $\infty$ & $\infty$ & $\infty$ & \\
\hline & & & & & 0 & 0 & $a$ & $\infty$ & & & & & & & & $\infty$ & $\infty$ & $\infty$ & $\infty$ & 580 & $\infty$ & $\infty$ & $\infty$ & $\infty$ & \\
\hline & & & & & $\alpha$ & 164 & & $\infty$ & & & & & & & & $\infty$ & $\infty$ & $\infty$ & $\infty$ & $\infty$ & $\infty$ & $\infty$ & $\infty$ & $\infty$ & \\
\hline & & & & & 100 & $\infty$ & & 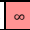 & & & & & & & & $\infty$ & $\infty$ & & $\infty$ & $\infty$ & $\infty$ & $\infty$ & $\infty$ & $\infty$ & \\
\hline & & & & & 0 & $\infty$ & $\infty$ & $\infty$ & & & & & & & & $\infty$ & $\infty$ & $\infty$ & $\infty$ & $\infty$ & $\infty$ & $\infty$ & 440 & $\infty$ & $\infty$ \\
\hline & & & & & $\infty$ & 0 & 136 & 220 & & & & & $\infty$ & & & $\infty$ & $\infty$ & $\infty$ & $\infty$ & $\infty$ & $\infty$ & $\infty$ & $\infty$ & $\infty$ & \\
\hline & $\infty$ & $\infty$ & & 154 & \begin{tabular}{|l|} 
\\
\end{tabular} & 136 & \begin{tabular}{|l|l|} 
\\
\end{tabular} & 320 & T. & $\infty$ & $\infty$ & $\infty$ & $\infty$ & & & $\mid \infty$ & $\infty$ & $\left.\right|^{\infty}$ & $|\infty|$ & $\infty$ & $\infty$ & $\infty$ & $\infty$ & $\infty$ & $\infty$ \\
\hline & & & $\infty$ & & $\infty$ & 220 & 320 & 0 & $\infty$ & $\infty$ & $\infty$ & $\infty$ & $\infty$ & $\infty$ & & $\mid \infty$ & $\infty$ & $\left.\right|^{\infty}$ & $\infty$ & $\infty$ & 146 & $\infty$ & $\infty$ & $\infty$ & $\infty$ \\
\hline & & & & & $\infty$ & $\infty$ & $\infty$ & $\infty$ & 0 & 92 & $\infty$ & 116 & 6 & $\infty$ & $\infty$ & $\infty$ & $\infty$ & $\infty$ & \begin{tabular}{|l|} 
\\
\end{tabular} & $\mid \infty$ & $\mid \infty$ & $\infty$ & $\infty$ & $\infty$ & $\infty$ \\
\hline & $\infty$ & & & & $\infty$ & $\infty$ & $\infty$ & $\infty$ & 92 & 0 & $\infty$ & $\infty$ & $\infty$ & $\infty$ & $\infty$ & $\infty$ & $\infty$ & $\infty$ & 460 & $\mid \infty$ & $\infty$ & $\infty$ & $\infty$ & $\infty_{\infty}$ & $\infty$ \\
\hline & & & $\infty$ & $\alpha$ & $\infty$ & $\infty$ & $\infty$ & $\infty$ & & $\infty$ & 0 & 260 & $0 \mid 222$ & $\mid \infty$ & $\alpha$ & $\infty$ & $\infty$ & & $\infty$ & $\infty$ & $\infty$ & $\infty$ & $\infty$ & $\infty$ & $\mu^{\infty}$ \\
\hline & $\infty$ & & & & $\alpha$ & $\infty$ & $\infty$ & $\infty$ & 116 & $\infty$ & 260 & & $\infty$ & & $\infty$ & 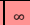 & $\infty$ & & $\infty$ & $\infty$ & $\infty$ & $\infty$ & $\infty$ & $\infty$ & $\infty$ \\
\hline & $\infty$ & $\infty$ & $\infty$ & $\alpha$ & $\infty$ & $\infty$ & $\infty$ & $\infty$ & $\infty$ & $\infty$ & 220 & 0 & 0 & 86 & $\infty$ & 240 & $\infty$ & $\infty$ & $\infty$ & $\infty$ & $\infty$ & $\infty$ & $\infty$ & $\infty$ & $\infty$ \\
\hline & $\infty$ & $\infty$ & $\infty$ & $\infty$ & $\infty$ & $\infty$ & $\infty$ & $\infty$ & $\infty$ & $\infty$ & $\infty$ & $\infty$ & 86 & & 84 & $\infty$ & $\infty$ & $\infty$ & $\infty$ & $\infty$ & $\infty$ & $\infty$ & $\infty$ & $\infty$ & $\infty$ \\
\hline & $\infty$ & $\infty$ & $\infty$ & $\infty$ & $\infty$ & $\infty$ & $\infty$ & $\infty$ & $\infty$ & $\infty$ & $\infty$ & $\infty$ & $\infty$ & 84 & 0 & 70 & $\infty$ & $\infty$ & $\infty$ & $\infty$ & $\infty$ & $\infty$ & $\infty$ & $\infty$ & $\infty$ \\
\hline & $\infty$ & $\infty$ & $\infty$ & $\infty$ & $\infty$ & $\infty$ & $\infty$ & $\infty$ & $\infty$ & $\infty$ & $\infty$ & $\infty$ & 240 & ||$^{\infty}$ & 70 & 0 & 150 & $\infty$ & $\infty$ & $\infty$ & $\infty$ & $\infty$ & $\infty$ & $\infty$ & 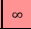 \\
\hline & $\infty$ & $\infty$ & $\infty$ & $\infty$ & $\infty$ & $\infty$ & $\infty$ & $\infty$ & & $\infty$ & $\infty$ & $\infty$ & $\infty$ & $\infty$ & $\infty$ & 150 & 0 & 60 & $\infty$ & $\infty$ & $\infty$ & $\infty$ & $\infty$ & 700 & $\left.\right|^{\infty}$ \\
\hline 18 & $\infty$ & 10 & $\infty$ & $\alpha$ & $\infty$ & $\infty$ & $\infty$ & $\infty$ & 10 & $\infty$ & $\infty$ & 380 & 0 & $\infty$ & $\infty$ & $\infty_{\infty}$ & \begin{tabular}{|l|l}
60 \\
\end{tabular} & 10 & \begin{tabular}{|l}
70 \\
\end{tabular} & $\infty$ & $\infty$ & $\infty$ & $\infty$ & $\infty$ & $\left.\right|^{\infty}$ \\
\hline 19 & $\infty$ & $\infty$ & $\infty$ & $\alpha$ & $\infty$ & $\infty$ & $\infty$ & $\infty$ & $\infty$ & 460 & $\infty$ & $\infty$ & $\infty$ & $\infty$ & $\infty$ & $\left.\right|^{\infty}$ & $\mid \infty$ & 70 & 0 & 30 & $\infty$ & $\infty$ & $\infty$ & $\infty$ & $\infty$ \\
\hline 20 & $\infty$ & 58 & $\infty$ & $\infty$ & $\infty$ & $\infty$ & $\infty$ & $\infty$ & $\infty$ & $\infty$ & $\infty$ & $\infty$ & $\infty$ & $\infty$ & $\infty$ & $\left.\right|^{\infty}$ & $a^{\infty}$ & $\infty$ & 30 & 0 & 86 & $\infty$ & $\left.\right|^{\infty}$ & $\infty$ & \\
\hline & $\infty$ & $\infty$ & $\infty$ & $\infty$ & $\infty$ & $\infty$ & $\infty$ & 146 & $\infty$ & $\infty$ & $\infty$ & $\infty$ & $\infty$ & $\infty$ & $\infty$ & $\infty$ & $\infty$ & $\infty$ & $\infty$ & 86 & 0 & 1110 & $\infty$ & $\infty$ & $\infty$ \\
\hline & $\infty$ & $\infty$ & $\infty$ & $\infty$ & $\infty$ & $\infty$ & $\infty$ & $\infty$ & $\infty$ & $\infty$ & $\infty$ & $\infty$ & $\infty$ & $\infty$ & $\infty$ & ]$^{\infty}$ & $\infty$ & $\mid \infty$ & $\infty$ & $\infty$ & 1110 & 0 & 25 & $\infty$ & 900 \\
\hline & $\infty$ & $\infty$ & $\infty$ & $\infty$ & 440 & $\infty$ & $\infty$ & $\infty$ & $\infty$ & $\infty$ & $\infty$ & $\infty$ & $\infty$ & $\infty$ & & $\infty$ & $\infty$ & $\infty$ & $\infty$ & $\infty$ & $\infty$ & 25 & 0 & $\infty$ & $\infty$ \\
\hline & $\infty$ & $\infty$ & $\infty$ & $\infty$ & $\infty$ & $\infty$ & $\infty$ & $\infty$ & $\infty$ & $\infty$ & $\infty$ & $\infty$ & $\infty$ & & & $\infty$ & 700 & $\infty$ & $\infty$ & $\infty$ & $\infty$ & $\infty$ & $\infty$ & 0 & 345 \\
\hline & a & & $\infty$ & & & & & & & & $\infty$ & $\infty$ & $\infty$ & & & $\infty$ & $\infty$ & & 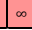 & $\infty$ & $\infty$ & & & 345 & \begin{tabular}{|l|l}
0 \\
\end{tabular} \\
\hline
\end{tabular}

\subsubsection{Graf Berbobot}

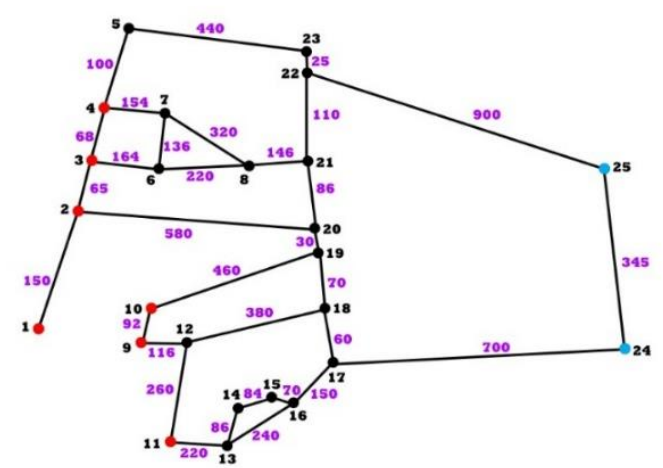

Gambar 9. Graf Berbobot

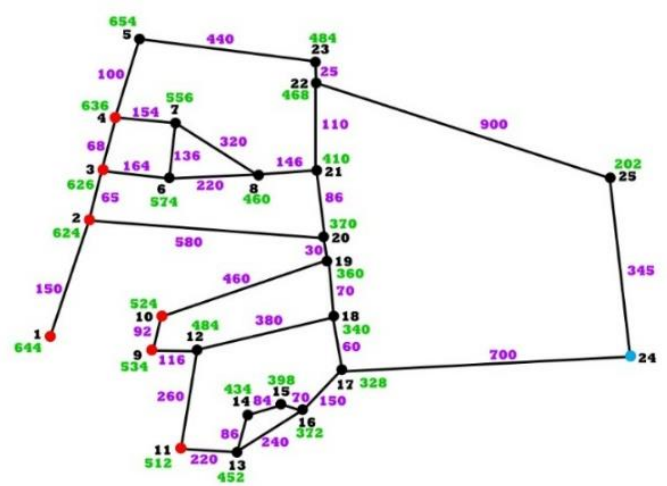

Gambar 1o. Graf Berbobot dengan Nilai Heuristik untuk Titik 24

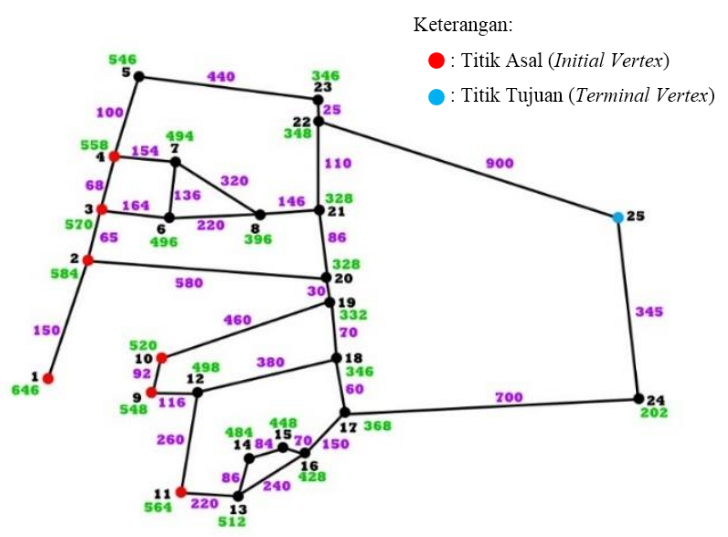

Gambar 11. Graf Berbobot dengan Nilai Heuristik untuk Titik 25

\subsubsection{Jalur Terpendek dengan Menggunakan Algoritma Floyd Warshall}

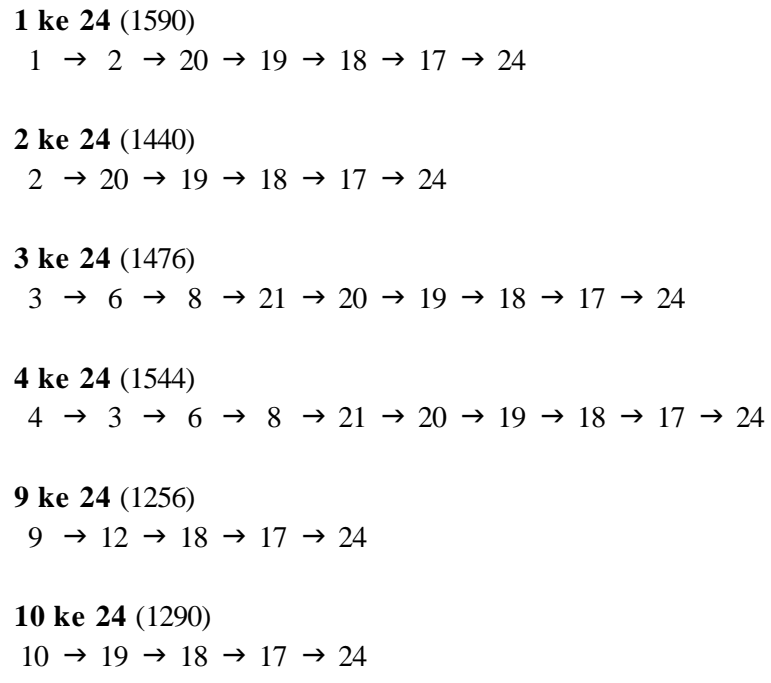

11 ke 24 (1310)

$11 \rightarrow 13 \rightarrow 16 \rightarrow 17 \rightarrow 24$ 
1 ke 25 (1748)

$1 \rightarrow 2 \rightarrow 3 \rightarrow 4 \rightarrow 5 \rightarrow 23 \rightarrow 22 \rightarrow 25$

2 ke 25 (1598)

$2 \rightarrow 3 \rightarrow 4 \rightarrow 5 \rightarrow 23 \rightarrow 22 \rightarrow 25$

3 ke 25 (1533)

$3 \rightarrow 4 \rightarrow 5 \rightarrow 23 \rightarrow 22 \rightarrow 25$

4 ke 25 (1465)

$4 \rightarrow 5 \rightarrow 23 \rightarrow 22 \rightarrow 25$

9 ke 25 (1601)

$9 \rightarrow 12 \rightarrow 18 \rightarrow 17 \rightarrow 24 \rightarrow 25$

10 ke 25 (1586)

$10 \rightarrow 19 \rightarrow 20 \rightarrow 21 \rightarrow 22 \rightarrow 25$

11 ke 25 (1655)

$11 \rightarrow 13 \rightarrow 16 \rightarrow 17 \rightarrow 24 \rightarrow 25$

\subsubsection{Jalur Terpendek dengan Menggunakan}

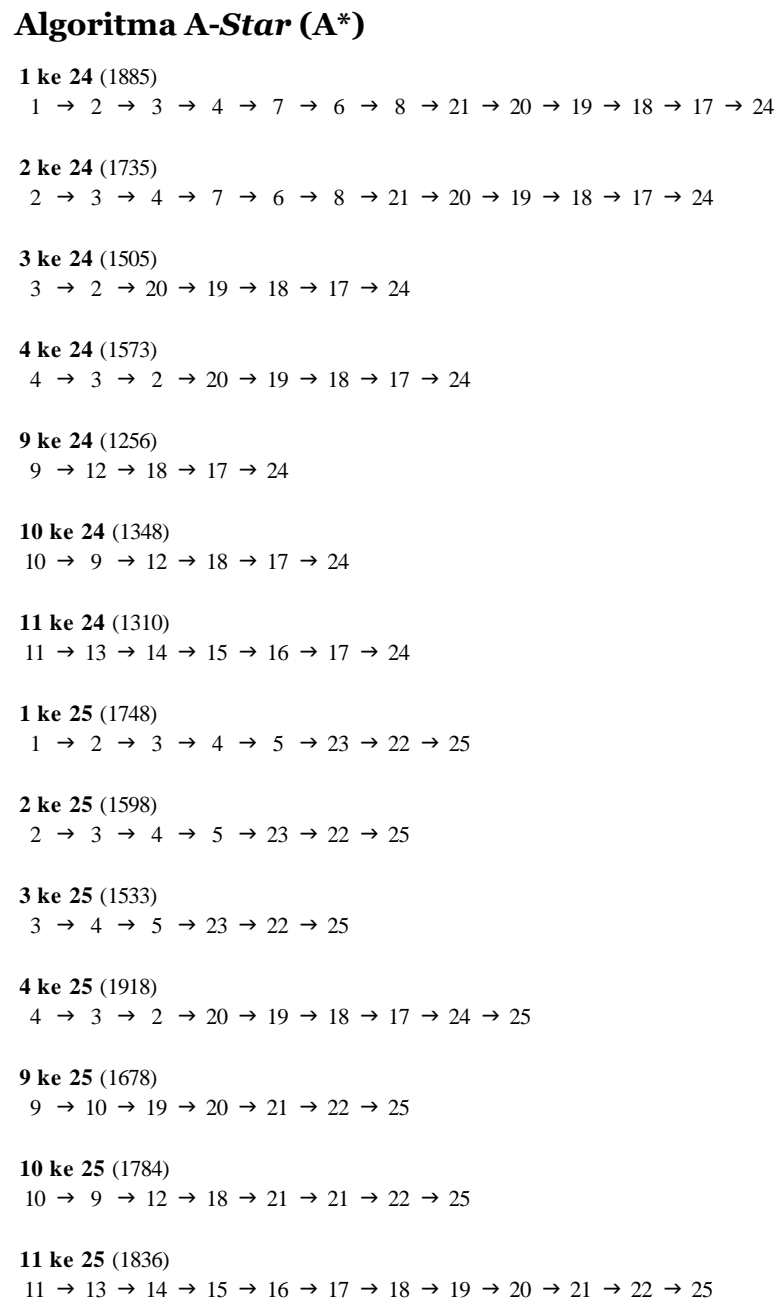

\subsection{Pembahasan}

\subsubsection{Model Jalur Evakuasi dengan Algoritma Floyd Warshall dan Algoritma A-Star ( $\left.\mathrm{A}^{*}\right)$}

Berdasarkan data daerah yang beresiko tsunami di Kota Manado khususnya Kelurahan Titiwungen Selatan yang diperoleh dari http://inarisk.bnpb.go.id/, dapat dibentuk graf yang titik-titiknya (vertices) merupakan persimpangan-persimpangan pada Kelurahan Titiwungen Selatan ditambah 4 lokasi lain, garisnya (edge) merupakan jalur evakuasi, dan bobotnya (Tabel 4) merupakan perkalian dari bobot jarak antara titik (Tabel 2) dan bobot akses jalan (Tabel 3). Setiap persimpangan pada Kelurahan Titiwungen Selatan direpresentasikan sebagai 1 titik ditambahkan dengan 4 titik diluar Kelurahan Titiwungen Selatan, sehingga terbentuk 25 titik.

Untuk mencari jalur terpendek dengan Algoritma AStar $\left(\mathrm{A}^{*}\right)$, diperlukan nilai heuristik. Pada Gambar 10 dan Gambar 11 terdapat nilai heuristik yang ditandai dengan teks berwarna hijau. Nilai heuristik pada Gambar 10 adalah jarak dari masing-masing titik ke titik tujuan (terminal vertex), yaitu 24. Sedangkan, nilai heuristik pada Gambar 11 adalah jarak dari masingmasing titik ke titik tujuan (terminal vertex), yaitu 25 .

Dari graf yang terbentuk, terdapat 25 titik. Dari 25 titik yang ada, dipilih 7 titik sebagai titik asal, yaitu lokasi yang berada di pinggiran daerah yang beresiko tsunami di Kelurahan Titiwungen Selatan. Dan dari 18 titik yang tersisa, dipilih 2 titik sebagai titik tujuan, yaitu lokasi yang berada di dataran tinggi dan merupakan daerah yang aman dari bencana tsunami. Karena terdapat 7 titik asal dan 2 titik tujuan, maka terdapat 14 jalur evakuasi.

\subsubsection{Perbandingan Jalur Terpendek dengan Menggunakan Algoritma Floyd Warshall dan Algoritma A-Star (A*)}

Hasil penentuan jalur terpendek dari Algoritma Floyd Warshall lebih optimal dibandingkan dengan Algoritma A-Star (A*) yang ditunjukkan dari hasil perhitungan bobot akhir dari tiap jalur evakuasi, dimana bobot jalur dengan menggunakan Algoritma Floyd Warshall lebih kecil dibandingkan bobot jalur dengan menggunakan Algoritma A*. Algoritma Floyd Warshall memperhatikan titik yang sedang dihitung dengan memperhatikan titik berikutnya sedangkan Algoritma A-Star $\left(\mathrm{A}^{*}\right)$ hanya memperhatikan titik yang sedang dihitung tanpa dipengaruhi oleh titik berikutnya. Hasil perbandingan jalur terpendek dengan menggunakan Algoritma Floyd Warshall dan Algoritma A-Star (A*) pada Tabel 5 . 
Penentuan Jalur Terpendek untuk Evakuasi Tsunami di Kelurahan Titiwungen Selatan dengan Menggunakan Algoritma Floyd Warshall dan Algoritma A-Star ( A $^{*}$ )

d'Cartesian : Jurnal Matematika dan Aplikasi, Vol. 8, No.1 (Maret 2019): 18-26

Tabel 5. Perbandingan Jalur Terpendek

\begin{tabular}{|c|c|c|c|}
\hline $\begin{array}{c}\text { Titik } \\
\text { Asal }\end{array}$ & $\begin{array}{c}\text { Titik } \\
\text { Tujuan }\end{array}$ & $\begin{array}{c}\text { Floyd } \\
\text { Warshall }\end{array}$ & A-Star \\
\hline 1 & 24 & 1590 & 1885 \\
\hline 2 & 24 & 1440 & 1735 \\
\hline 3 & 24 & 1476 & 1505 \\
\hline 4 & 24 & 1544 & 1573 \\
\hline 9 & 24 & 1256 & 1256 \\
\hline 10 & 24 & 1290 & 1348 \\
\hline 11 & 24 & 1310 & 1310 \\
\hline 1 & 25 & 1748 & 1748 \\
\hline 2 & 25 & 1598 & 1598 \\
\hline 3 & 25 & 1533 & 1533 \\
\hline 4 & 25 & 1465 & 1918 \\
\hline 9 & 25 & 1601 & 1678 \\
\hline 10 & 25 & 1586 & 1784 \\
\hline 11 & 25 & 1655 & 1836 \\
\hline
\end{tabular}

\section{Penutup}

\subsection{Kesimpulan}

Berdasarkan hasil analisis dari Algoritma Floyd Warshall dan Algoritma A-Star (A*) dapat disimpulkan bahwa dalam penentuan jalur terpendek untuk evakuasi tsunami, hasil dari Algoritma Floyd Warshall lebih optimal dibandingkan dengan Algoritma A-Star ( $\left.\mathrm{A}^{*}\right)$. Sehingga, jalur terpendek untuk evakuasi tsunami di Kelurahan Titiwungen Selatan diambil dari hasil perhitungan dengan menggunakan Algoritma Floyd Warshall, yaitu sebagai berikut:

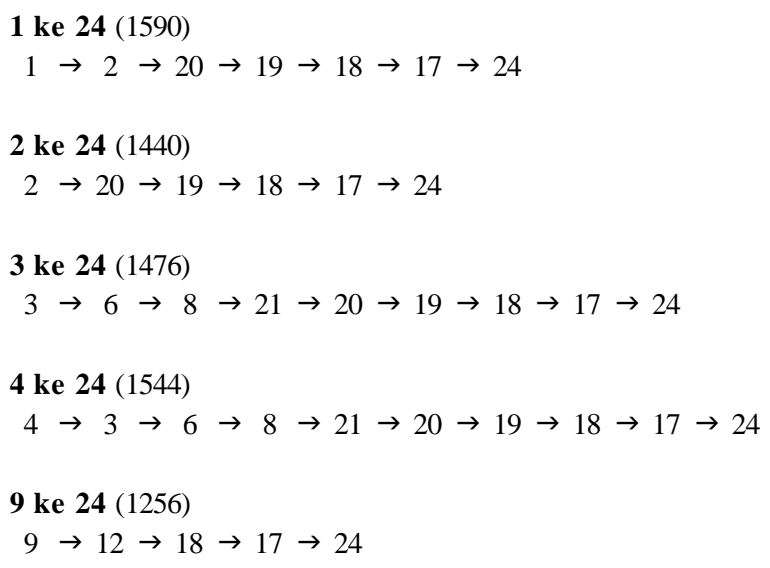

10 ke 24 (1290)

$10 \rightarrow 19 \rightarrow 18 \rightarrow 17 \rightarrow 24$

11 ke 24 (1310)

$11 \rightarrow 13 \rightarrow 16 \rightarrow 17 \rightarrow 24$

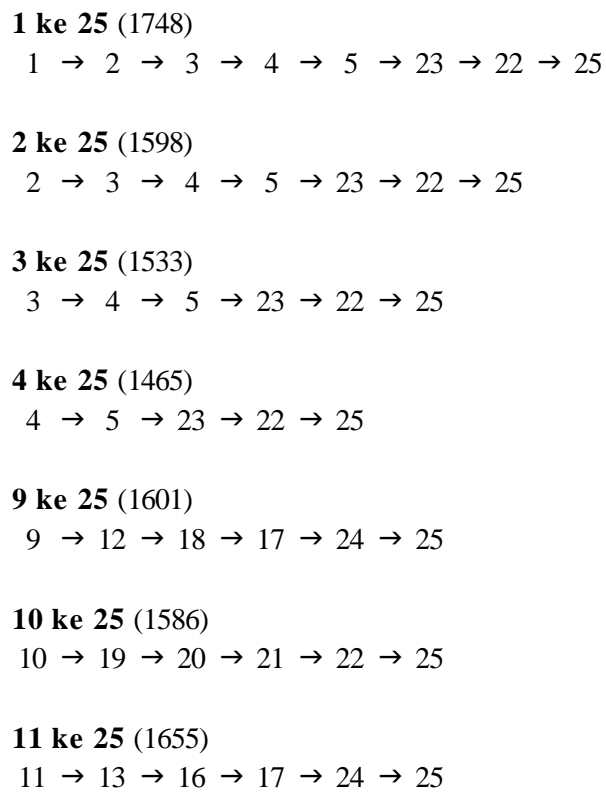

\subsection{Saran}

Perlunya penelitian dan pengembangan lebih lanjut mengenai jalur evakuasi tsunami di Kelurahan lainnya dan faktor-faktor lain yang mempengaruhi saat evakuasi tsunami berlangsung selain jarak dan ukuran jalan. Penelitian ini diharapkan dapat membantu pemerintah dalam pembuatan jalur optimal untuk evakuasi tsunami khususnya di Kelurahan Titiwungen Selatan.

\section{REFERENSI}

[1] BMKG. 2012. Buku Pedoman Pelayanan Peringatan Dini Tsunami InaTEWS. Badan Meteorologi Klimatologi dan Geofisika (BMKG) dan GTZ-IS GITEWS, Jakarta.

[2] Fatimah, F dan T. Rajati. 2012. Menentukan Lintasan Terpendek Evakuasi Tsunami di Kota Padang. http://repository.ut.ac.id/5796/ [2 Oktober 2018].

[3] Harris, J.M., J. L. Hirst, and M. J. Mossinghoff. 2008. Combinatorics and Graph Theory. Edisi ke2. Springer, New York.

[4] Munir, R. 2010. Matematika Diskrit. Edisi ke-3. Informatika, Bandung.

[5] Pijls, W. and A. Kolen (1992). A General Framework for Shortest Path Algorithms. Technical Report 92-08, Erasmus University Rotterdam.

[6] Purwananto, Y., D. Purwitasari, dan A. W. Wibowo. 2005. Implementasi dan Analisis Algoritma Pencarian Rute Terpendek di Kota Surabaya. Jurnal Penelitian dan Pengembangan TELEKOMUNIKASI. 10(2): 94-101.

[7] Putra, A. T., Rumani, dan M. W. Paryasto. 2017. Perbandingan Kompleksitas Algoritma A-Star, Floyd-Warshall, Viterbi pada SDN (Software Defined Networking). e-Proceeding of Engineering . 4(3): 4001-4006. 
[8] Rompis, A. 2018. Mitigasi Bencana Belum Memadai Padahal Kota Manado Pernah Diterjang Tsunami Setinggi $20 \quad$ Meter. http://www.tribunnews.com/regional/2018/10/02 /mitigasi-bencana-belum-memadai-padahal-kotamanado-pernah-diterjang-tsunami-setinggi-20meter [4 Oktober 2018].

[9] Rosen, K.H. 2012. Discrete Mathematics and Its Applications. $7^{\text {th }}$ Edition. McGraw-Hill, New York.

[10] Sani, A. F., N. K. T. Tastrawati, dan I. M. E. Dwipayana. 2013. Algoritma Floyd Warshall untuk Menentukan Jalur Terpendek Evakuasi Tsunami di Kelurahan Sanur. E-Jurnal Matematika. 2(1): 1-5.

[11] Supartoyo. 2016. Kegempaan di Sulawesi Utara. http://geomagz.geologi.esdm.go.id/kegempaan-disulawesi-utara/ [4 Oktober 2018].

[12] Tilawah, H. 2011. Penerapan Algoritma A-star (A*) untuk Menyelesaikan Masalah Maze. Makalah IF3051 Strategi Algoritma. Program Studi Teknik Informatika, ITB, Bandung. http://informatika.stei.itb.ac.id/ rinaldi.munir/St mik/2011-2012/Makalah2011/MakalahIF30512011-009.pdf [2 November 2018].

[13] Undang-Undang RI No. 24 Tahun 2007 tentang Penanggulangan Bencana.

[14] Wallis, W.D. 2007. A Beginner's Guide to Graph Theory. Birkhauser, Boston.

[15] Wardhani F. P., A. Johar, dan Y. Fauzi. 2014. Manajemen Basis Data Sarana Kampus Universitas Bengkulu Menggunakan Algoritma $A^{*}$ Berbasis Spasial. Jurnal Rekursif. 2(2): 121-128.

[16] https://bnpb.go.id/definisi-bencana [4 Oktober 2018].

[17] https://bnpb.go.id/potensi-bencana $\quad[4$ Oktober 2018].

[18] http://www.gocelebes.com/manado-sulawesiutara/\#section-geografi [4 Oktober 2018].

[19] http://pusatkrisis.kemkes.go.id/tips-siagabencana-tsunami [30 Januari 2019].

Stephanie E. Chungdinata (stephanielysia@gmail.com)

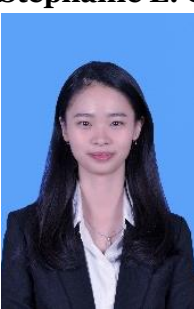

Lahir di Manado, Sulawesi Utara pada tanggal 16 September 1997. Menempuh pendidikan tinggi Jurusan Matematika, FMIPA, Universitas Sam Ratulangi Manado. Tahun 2018 adalah tahun terakhir ia menempuh studi. Makalah ini merupakan hasil penelitian skripsinya yang dipublikasikan.

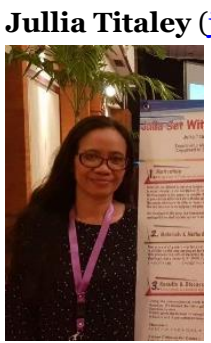

uly titaley@unsrat.ac.id

Pada tahun 1997, memperoleh gelar sarjana di Program Studi Matematika, Universitas Pattimura Ambon. Gelar Magister Sains diperoleh dari Universitas Gajah Mada pada tahun 2001. Menjadi dosen di Jurusan Matematika, FMIPA, Universitas Sam Ratulangi Manado sejak tahun 2002 sampai sekarang dengan bidang keahlian yang ditekuni diantaranya; Analisis, Aljabar, dan Geometri.

Chriestie E.J.C. Montolalu (Chriestelly@yahoo.com)

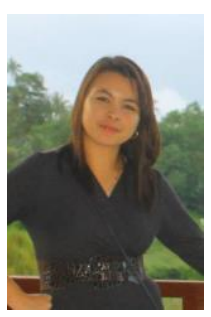

Lahir pada tanggal 10 Desember 1985 Pada tahun 2007 mendapatkan gelar Sarjana Sains (S.Si) yang diperoleh dari Universitas Sam Ratulangi Manado. Gelar Master Of Science (M.Sc) diperoleh dari Universitas Of Queensland Australia pada tahun 2015. Ia bekerja di UNSRAT di Program Studi Matematika sebagai pengajar akademik tetap UNSRAT. 